\title{
Hydra: A Creative Training Tool for Critical Legal Advocacy and Ethics
}

\author{
Sara Ramshaw, Adnan Marquez-Borbon, Seamus Mulholland, and Paul Stapleton ${ }^{1}$
}

\section{Introduction}

What makes good teachers great? This is the question posed by Keith Sawyer in his chapter by the same name. His answer? Improvisation. Expert educators, Sawyer suggests, fully appreciate that teaching, when done well, is an improvisational activity that is collaborative and emergent in nature, that balances structuring elements, such as educational policies and/or government guidelines, with reflective practice that is dialogic and responsive to student needs and to the pedagogical environment ("What Makes" 2; "Creative Teaching" 13). Learning is equally improvisational. No two students absorb exactly the same content in the same manner and at the same speed, and the most inspired students develop bespoke study habits or strategies for learning (Erickson 131).

In a similar vein, we ask here: what makes good law students great legal advocates? Our answer mirrors Sawyer's: improvisation.

From the outset, we must clarify that our desire to teach law students and trainee barristers ${ }^{2}$ to become better improvisers is not meant to encourage them to become better at flouting the rules, or make them more skilled at "game playing" or manipulating the legal system. ${ }^{3}$ Instead, following critical improvisation scholars such as Sawyer, Fischlin, and Heble, improvisation is for us a disciplined (Sawyer, "What Makes" 2; "Creative Teaching" 13) or social practice (Fischlin and Heble 11) that does not entail simply making up the rules as one goes along, but is instead guided by existing structures while also facilitating opportunities for choice and the possibility of inventiveness ${ }^{4}$ for participants (Erickson 130; see also the Improvisation as Pedagogical Practice section below).

Great legal advocates do not simply read from a script: they may work within a "rule structure" of courtroom documents, precedents, procedures, statutes, and legislation (and of limited resources and time ${ }^{5}$ ), but skilled barristers also have to be highly attuned, attentive, and responsive-both within and outside the courtroom-to the unfolding of a case. One of the first female High Court judges in Northern Ireland, ${ }^{6}$ Dame Siobhan Keegan (DBE, QC_-and a brilliant advocate herself), noted the following at our May 2015 Just Improvisation Symposium: ${ }^{7}$

there are voluminous papers, but that will never prepare me for what happens in the court because I don't know what the witness is going to say. I don't know what is going to be thrown up. I don't know if the judge is going to be receptive to my argument, or whether the judge is going to, by telling me, or by me picking it up, "don't go there with that argument." So, that is a dynamic process . . And, that's part of the trial process, and to be honest that's why I am a barrister because the outworkings of trials are myriad and surprise me all the time. ${ }^{8}$ (emphasis added)

Former Lord Chief Justice of Northern Ireland and UK Supreme Court justice the Right Honourable Lord Kerr of Tonaghmore (speaking in a BBC documentary entitled The UK Supreme Court: the Highest Court in the Land about the nature and quality of advocacy and judicial conduct in proceedings before the Supreme Court) has also remarked that "the nimble-footedness of counsel, the improvisational ability, the capacity to switch tack ... are all very impressive." As Justice Kerr acknowledges, improvisation is thus very much already taking place in the best advocacy and the best judgments. ${ }^{9}$ That being so, it is vital to teach law students and trainee barristers the skills of improvisation to make them more creative, critical, and ethical legal advocates who can (1) offer new solutions to both predictable and unpredictable developments in and outside the courtroom; (2) be analytically attentive, evaluative, and reflective in relation to these responses; and (3) be open and empathetic to otherness, both in terms of the known and unknown. ${ }^{10}$

Recognizing the importance of improvisation in relation to expert legal advocacy, this article proceeds first with a discussion of the necessity of creative advocacy in contemporary Western common-law legal systems. We then outline the utility of improvisation as a pedagogical practice and sketch this pedagogy as it applies to legal advocacy through an introduction and explanation of the creative training tool Hydra. The aim of this article is to demonstrate the potential of Hydra to inspire creativity, criticality, and ethics in the lawyers of tomorrow and, in doing so, suggest redefining legal advocacy pedagogy and training as essentially improvisational in nature (Sawyer, "Creative Teaching" 12).

\section{Creative Legal Advocacy}

Uninspired pedagogy can inhibit creative legal advocacy (Little 234). Schneider and Hanna contend that only by expanding legal educational opportunities for students is it possible to develop "more committed, sensitive, thoughtful, and effective lawyers . . . in the future. In this way, creative legal advocacy . . . will continue to grow and be enriched by new perspectives" (349-50)..$^{11}$ 
While there are many other "new perspectives" or pedagogical approaches currently being utilized, especially in the United States, to produce more creative and ethical legal advocates-Creative Problem Solving (see, for example, Cooper; Kerper; Krieger; Menkel-Meadow; and Rogers), the Comprehensive Law Movement (Daicoff), and Therapeutic Jurisprudence (Winick and Wexler) —outlined below is a creative improvisational pedagogical tool called Hydra, developed in Northern Ireland by the Into the Key of Law research team.

Before introducing Hydra, it is necessary to ask why we need creative legal advocates in the first place. Whenever one seeks to convey a message and elicit a desired response, creativity is crucial to garnering success. For the legal advocate, each case has its own peculiar issues of fact and law, a narrative that, in an adversarial system, is necessarily generated from having to engage with the counter-narrative that one's opponent sets out. Without a beneficial narrative, one can contribute next to nothing to a case.

Improvisation is pivotal to maximizing creativity (Beghetto and Kaufman 97). One can be creative in the preparation of a narrative, but without the ability to improvise in the crucial moments of actual presentation, creativity meets a premature terminus. Responding to factors that cannot be wholly anticipated-counternarratives, unpredictable witnesses, the developing responses of decision-makers-ultimately ensures justice. In this sense, improvisation is a stimulant, allowing creativity to go on producing benefits for a greater duration than would otherwise be the case.

Creativity, as a catchall word, necessarily embraces so many other skills. The environment in which an advocate creates is one where mental agility is highly prized: the ability to listen, analyse, and reinforce or challenge second by second what is being said. And, perhaps more than others involved in the art of persuasion, the advocate has ethical and legal boundaries in which to operate. There may be facts to explore, but also stumbling blocks to which one must fashion a solution. In this sense, rather than stymying creativity, the need to craft a smooth legal narrative requires greater creativity.

A lack of creativity in legal interpretation leaves the law stagnant and incomplete; a fundamental tenet of the common law system is that judges and counsel be creative in completing that system. As Ramshaw has written elsewhere,

The dominant understanding of the common law tradition is complicated by the fact that no two cases appearing before a court for judgment can be exactly the same. There will always be some distinction or dissimilarity; no two actions take place at the exact same time, with the exact same parties and the exact same factual situations. This distinction forms the basis of the adversary system in which two opposing sides struggle to convince a judge or jury that her or his interpretation of the case law, statute, or regulation is the most persuasive and should be accepted as "the truth." Cases that are strikingly similar to previous decisions rarely make it before a judge because, if it is impossible to contradict or distinguish a past precedent, the outcome will basically be known or guaranteed in advance and settlement out of court, to save on the enormous expense of adjudication, would most likely be suggested and encouraged. Thus, each judicial application of existing rules or past precedents to new facts creates, in fact, a new and improvised law. Novelty and creativity, however, must be subordinated to tradition and precedent in order for law to remain legitimate and commanding in contemporary society. Law, in other words, cannot be seen to be produced "on the spur of the moment." ("Jamming" 133-34; see also Justice)

Case law is said to evolve to complement statute law. Parliament creates statutes, with desired outcomes for which there is a keenness to bring about a quick realization. In daily implementation, barristers know best the existing terrain that must be negotiated, and they assist judges in laying a suitable course for each case by accounting in real time for two ever changing variables: facts and people. This is creativity, and improvisation is how it functions in crucial decision-making moments.

To be sure, the consequences of legal advocacy are much more immediate and decisive than many other ventures in narrative, any of which should engage, inform, and enlighten-but immediacy and decisiveness are pivotal here because a real decision is required in this moment. Once encountered, there is no letup from the law until its effect has been fully felt and appreciated, and in comparison even to other spheres of law, the gravity of legal advocacy is most pronounced. Consider in contrast the narratives that play out within legislatures: statute law is made there, but legal advocacy transcends the abstract with real application into real people's lives. This demonstrates all the greater need for creative advocates. An abstract law can rarely account for all the nuances and subtleties of those who are governed by it, nor is it meant to: working within a social science, litigants, judges, and lawyers are expected to enliven the practice of law. A lack of creativity switches off this expectation and is anathema to, and a dereliction of, what it is to be an advocate.

The following section focuses on how critical legal advocacy could be achieved through a discussion of the pedagogy of improvisation. Particular attention is paid to John Zorn's improvisational "game piece" Cobra, which provided the inspiration for Hydra. 


\section{Improvisation as Pedagogical Practice}

While Bailey has expressed that improvisation is the most widely spread musical practice in the world, within Western European art music, it is notably absent from conservatory education. ${ }^{12}$ In contrast to oral musical traditions, the main objective of formal, classical, music education is developing the skills to accurately read and perform scores and achieve instrumental virtuosity. Improvisation (particularly jazz) in academia has a complex history originating from its initial uptake in the 1960s, when it was resisted by many scholars as a lesser and "anarchic" music form (Prouty 2). In recent times, however, jazz education has been accepted and become much more widespread within higher education institutions.

Despite the inclusion of (jazz) improvisation in performance programs, critics of current curricula and teaching practices have observed that the teaching of musical improvisation employs methods from formal traditional music where theory and practice are separated, imitation is stressed, and individual facility or technique is privileged at the expense of creative and social skills (Borgo; Prouty). Supporters of improvisation in music education, as both practice and method, suggest that improvisation-based pedagogy should be at the core of music curricula because it helps students develop heightened listening skills, musical agility, and adaptability, thereby making them better ensemble performers (Sawyer, "Improvisation and Teaching" 1).

Criticisms of traditional music education also stress how it emphasizes passive learning from an authoritarian teacher who determines what is to be learned (Lange 5). As Sawyer discusses, education should be particularly focused on developing deep conceptual understanding, integrated (contextualized) knowledge, adaptive expertise, and collaborative skills ("Improvisation and Teaching" 2). Indeed, learning that relies on improvisation benefits from loosely structured environments that support purposeful, critical, practical activities and embodied, situated knowledge (Borgo; Sawyer; Ross; Lange). Regarding the inclusion of improvisational strategies within physical education, Ross observes that

Learning through improvisation entails a transformation in which learners change with the work they are co-creating. As a result, indeterminacy is a key feature of improvisation, and the constraints that guide responses, invite, nay demand, creative problem solving in real time. Improvisation, as with sports play, requires players to think on their feet ... (1)

Such education is thus necessarily developed as a collaborative and social practice. In effect, advocates of improvisation as pedagogy pursue greater social goals beyond mere musical production. As Thomson suggests,

authentic improvisers emerge, not "out of nowhere," but from the social, pedagogical framework of improvisation itself. Intersubjective communication, articulated in the negotiative space created within performance, is contingent on the recognition of differences that defy objective, instrumentalist methods of reconciliation; "musical" methods give way to "social" ones in a piecemeal pedagogical moment. (7)

Lewis further observes that autodidactic pedagogy communities (such as the AACM and BAG) not only help to develop new musical and aesthetic practices, but also contribute to the "revitalization of US communities of color in the face of severe economic privation" (1). Improvisation within this social dimension empowers the exercise of self-determination, community development, and socio-political activism and critique. Put another way, the pedagogy of improvisation represents an egalitarian practice where authority is a fluid, temporal concept negotiated amongst members of a group (Thomson; Lange). ${ }^{13}$

\section{Cobra: Adopting Musical Techniques for Improvisation Pedagogy}

Cobra (1984) is perhaps John Zorn's most well-known composition, an example of the strategy to structure or control improvisation through a set of rules, much in the spirit of sports or strategic games, hence the namesake for the piece (see Brackett 45). Despite these rules, however, Cobra has no preconceived sequences, musical content, or explicit instrumentation. The composition itself consists of a set of rules (codified as cue cards) that structure the piece by directing different individual and group actions, and a "prompter" who moderates the application of these rules. Players also have agency to either select or override different rules presented by other players or the prompter-and a particularly interesting subset of rules provides a further opportunity to form smaller "guerrilla" groups independent of the larger ensemble. ${ }^{14}$ The number of players, instrumentation, and length of the piece are indeterminate. The prompter is not a conductor in the traditional sense, but more of a guide who can relay information within the group and select or ignore requests from musicians. The piece is directed by the decisions and actions of the performers themselves, and thus may sound radically different from performance to performance.

The deliberate usage of the term prompter, as opposed to conductor, along with the creative agency granted to performers, creates a less hierarchical environment than that found in a symphonic orchestra. As Zorn acknowledges, however, the context provided by Cobra reflects human society-its dynamic power relationships of domination, submission, subversion, and resistance-on a microscopic scale (Brackett 56). 
In assessing his experience playing with Zorn at the Festival International de Musique Actuelle de Victoriaville, Quebec in May 2003, van der Schyff describes how

Keeping track of one's own musical trajectory while simultaneously remaining aware of the manifold and auditor cues continuously occurring all around was also extremely challenging. Cobra exaggerates the degree to which all music performance depends on the communication of musical and other interpersonal signs - which may involve physical movement, including bodily and facial gestures, as much as sound...

Furthermore, Cobra demands a deep personal understanding of one's own musical arsenal as an improviser, as well as the "open skills"-the musical, technical, conceptual flexibility ... - - required to adapt to the complex demands of the moment. (5-6)

Zorn deliberately chose to not publish or write down the rules of Cobra, because he saw them as part of an oral tradition (Brackett 47). Unsanctioned, annotated copies of the score are available, but there are differences in the rules between Zorn's "authorized" versions ${ }^{15}$ and these "outlaw" interpretations of the piece. ${ }^{16}$ Nonetheless, these unsanctioned scores have allowed musicians to learn and perform the piece.

One "outlaw" version is that performed by QUBe, an experimental music collective based at the Sonic Arts Research Centre (SARC), Queen's University Belfast. ${ }^{17}$ QUBe appropriated Cobra into a pedagogical tool for improvisation by gradually introducing the full score over a period of months, initially limiting the use of guerrilla tactics, and reducing the number of cards to only the most essential. In this manner, novices are introduced to group improvisation in a less intimidating context. The limited rules and imposed constraints place the responsibility for structuring the piece upon the group as a whole rather than on individual performers, making it easier and faster for learners to engage with improvisation. Additionally, because of the open nature of the piece-the primacy of structure over sound (Brackett 71$)^{18}$ - there is no predetermined "idiom" that might alienate players with different backgrounds and experience. The QUBe version of Cobra promotes a fun and supportive learning environment that significantly improves performer confidence.

\section{Hydra: A Pedagogical Tool for Critical Improvisation in Law}

This section of the paper will introduce and explain the key tenets of the improvisational "game piece" Hydra, which we created after being inspired by a version of Zorn's Cobra performed by members of the Translating Improvisation Research Group ${ }^{19}$ for an improvisation workshop involving lawyers, postgraduate law students, legal academics, and improvising musicians at SARC on June 25, 2014.

As van der Schyff notes above in relation to improvising musicians, barristers, and law students too require "open skills" to adapt to the "complex demands of the moment" in a courtroom. We saw such verbal, technical, and conceptual flexibility when QUBe performed Cobra on that fateful day in June $2014 .^{20}$

\section{What is Hydra?}

Traditional moot court or legal advocacy training is often criticized for failing to adequately prepare advocates to be nimble-footed in the courtroom. In contrast, Hydra (named after the serpent-like water monster with numerous heads in Greek mythology) hones legal argumentation skills, requiring participants to be "Hydra-headed": prepared for the unexpected, skilled at rapidly analyzing legal issues from a variety of angles and perspectives. Hydra teaches participants to, within the same case,

- Move to a new thread of argument.

- Rehearse an argument already advanced.

- Become a witness.

- Advocate on behalf of a different party.

- Deal with a witness going off script by

- Rebutting what the witness has said through recollection of contradictory evidence.

- Leading the witness to a conclusion that assists the advocate's argument.

- Be at ease with overarching techniques of advocacy and improvisation.

- Cope better with unexpected disruptions and uncertainties.

- Condense an argument to fit different time limits.

Hydra begins with a fact scenario of a legal case and an overview of the basic laws relating to this scenario. In the initial pilot of Hydra, ${ }^{21}$ we used facts from a real child protection case and the related "welfare of the child" legal test. Participants acted as (1) barrister for the mother, (2) the mother herself, (3) barrister for the father, (4) the father himself, (5) barrister for the local Health and Social Care Trust / Local Authority, ${ }^{22}(6)$ the social worker, and (7) the judge (somewhat similar to the "prompter" in Cobra). Through the use of "judicial" cue cards or hand gestures communicated to the judge, participants forward legal arguments in relation to the case, but could at 
any point in time be directed by the judge (as either a conduit of the participants or of her own accord) to switch arguments, switch roles, argue for the opposing side, increase or decrease their speaking volume, end an argument abruptly, or expand an argument. Participants can also be witnesses who add information to the fact scenario and are cross-examined by the barristers. In addition, following our focus groups with local legal professionals, the latest version of Hydra allows the judge to actively respond to and challenge arguments put forward by participants and to switch roles with other participants (see Appendices A and B for further information).

\title{
Why Hydra?
}

Through Hydra, we hope to directly impact how law students, members of the legal profession, and the general public view improvisational practices; combatting the common myth that improvisation is simply "making it up as you go along," an entirely spontaneous activity not constrained by expertise, cultural history, or social norms. Improvisation is better understood as the ability to apply prior knowledge and expertise to dynamically unfolding situations that frequently require deviation from normative behaviour. Conceived as such, improvisation is not just a musical process, but also a social practice, one that involves creative decision-making, risk-taking, trust, and collaboration. Not entirely intuitive, improvisation must be learned and honed. Improvised musical practices thus speak not only to music, but to other realms such as law and justice.

The improvisational practices taught and honed through Hydra help law students (as future barristers and solicitors) to master the fundamental tools of skilled advocacy, such that they can produce compelling argumentation and reasoning extemporarily. This process allows students to safely hone their verbal agility and attentive listening skills, the latter an essential tool for a responsible and ethical advocate.

\section{What are the Limitations of Current Legal Advocacy Training that Hydra will Address?}

\author{
According to the University of Exeter Law School's ${ }^{23}$ Mooting Handbook:
}

The benefits of mooting are extensive. Mooting affords you the opportunity to develop your understanding of the law and to improve your skills in legal research and analysis. When you moot, you learn to develop and defend your arguments, in a way that serves to increase your confidence and improve public speaking skills. You will also work closely with teammates towards a common goal. Mooting also allows for interaction between students and members of academic staff, legal practitioners and judges, in a rewarding environment. For these reasons, mooting is recognized as an excellent addition to the $\mathrm{CV}$ for students wishing to enter legal practice, whether as barristers or solicitors. (1) ${ }^{24}$

Despite these "extensive benefits," legal academics (including Bobette Wolski, Associate Professor at Bond University's Faculty of Law in Australia) have expressed a number of concerns about the use of mooting in law schools. Some criticisms, which Hydra addresses, are as follows:

\section{1) Lack of opportunity to develop awareness of ethics and values}

One limitation of the "traditional moot," notes Wolski, is that it "provides limited opportunity for students to gain an understanding and awareness of legal ethics and values (as opposed to an understanding and awareness of court etiquette)" (42; see also Macfarlane 310, and Keyes and Johnstone 559). Admittedly, mooting teaches some very basic rules of courtroom etiquette and professional conduct. According to Wolski,

Students should be exposed to, and given the opportunity to question, broader issues of professional responsibility such as those pertaining to:

- $\quad$ The advocate's role in the legal system and in society;

- The issue of who, in the lawyer-client relationship, chooses which issues to run and which to ignore;

- The question of whether or not an advocate needs to believe that justice is on the client's side; and

- Whether or not a court is the appropriate forum to resolve the matter at hand. (48)

In addition, she argues that legal academics have

an obligation to impart to our students a critical understanding of personal and professional values. Values are beliefs or principles of importance to an individual or group that serve as a yardstick by which an individual or group can evaluate alternative and sometimes conflicting courses of action. (48) 
A vital component of productive improvisation is "deep" or "attentive listening," an ethical commitment to interact with and be responsible for the people and the environment around us (Fischlin and Heble 11; see also Oliveros). Developing this ability to listen and respond with respect requires both education and practice. As a creative training tool, Hydra enhances empathy and adaptability by teaching future advocates to embrace unpredictability, uncertainty, error, and failure as opportunities for learning.

The above sentiment notwithstanding, Ramshaw often speaks of the "dark side of improvisation" in law and has written about the thin line that exists between justice as improvisation and improvised illegality ("The Creative Life"; "Improvising (II)legality"). Derek Attridge, writing about the flourishing of Nazism, sounds a similar warning:

What is the ethical ground for attention to and affirmation of otherness, when the result of this effort may be without any humanly recognizable merit, or indeed-since the other that is brought into being may. . . turn out to be a monstrosity — may serve quite inhuman ends? (126)

Tracey McMullen, in an interview with Judith Butler, highlights Todorov's assessment that Cortés' conquest of the Aztecs was made possible through his "constantly practicing the art of adaptation and improvisation" (Todorov 87 ) as evidence that "improvisation is not inherently some ethical phenomenon" (McMullen 30). ${ }^{25}$

Fischlin and Heble disagree. For them, "Todorov gets it wrong":

To have been truly improvisatory in the relation to otherness that Cortés initiates, would have required his turning away from the predictable acts of imperial greed and destruction to initiate something quite different-like a peaceful and productive alliance with indigenous cultures in the name of forming a transcultural community based on dialogue and "true" improvisation rather than on the monological deployment of European power. (15)

Although space does not exist here to explore this issue fully, it is our position that, although improvisation can never be completely and essentially ethical (Ramshaw, Justice 122-29), it does have the possibility of "calling forth the unexpected" (Fischlin 1), of making possible "a more creative vision of justice and social change" (Ramshaw, Justice 130).

\section{2) Anxiety caused by mooting}

While some might perceive moots as "fun," Wolski notes that "many students report that participation in moots induces feelings of 'terror' and 'fear and stress' in them" (67; see also Lynch 88-91). The more overwhelmed or anxious students are, the more likely they will "adopt a surface approach to learning in order to cope" (Wolski 6768). Given the level of competition in law schools for marks and future opportunities, students are often reluctant to engage whole-heartedly in advocacy training exercises for fear of making mistakes in front of peers and thereby tainting their reputations-which are of the utmost professional importance, especially for future barristers (who in the UK are self-employed). ${ }^{26}$

While improvised argumentation without the safety net of extensive notes may be equally daunting to many (see Shaw and Stacey in the context of business organizations), sustained training in this process allows students to respond with far greater confidence to uncertainty. By focusing on nimble thinking and verbal dexterity, rather than determining right or wrong answers, Hydra can enhance a law school's advocacy and employability skills training.

\section{3) Ignoring the facts}

Another limitation of the "traditional moot" is that it is typically concerned with legal issues at the appellate level, where facts are determined in advance and remained fixed throughout. As such, it does not offer the opportunity or the flexibility to interpret evidence.

While it is extremely important that students learn how to apply the law to predetermined facts, in Hydra, the law is relatively straightforward, while the "facts" contain conflict and ambiguity-a more accurate representation of real legal contexts "where people give contradictory accounts of an event and where there are variations in evidence" (Wolski 56).

\section{4) Weak oral presentation skills}

Wolski's research indicates that the traditional moot does not necessarily strengthen law students' oral presentation skills. She has found the most common weaknesses to be

- Poor communication skills (for example, speaking too quickly, using distracting mannerisms, and 
not making or maintaining eye contact).

- $\quad$ Overreliance on written notes.

- $\quad$ Lack of selectivity in choosing the arguments to advance to the court. Some students left their strongest arguments until last, and invariably, ran out of time to deal with them.

- Difficulty answering questions from the bench.

- $\quad$ Failure to identify and adapt to the court's concerns.

- $\quad$ Lack of understanding of basic techniques of persuasion. (67)

In relation to teamwork, other weaknesses include "failure to share the workload equitably, incorrect and inappropriate division of functions . . . and failure to divide and deal with relevant issues in a logical and cohesive manner" (67).

Hydra, on the other hand, relies heavily on attentive listening and improvisational agility: participants must be prepared at all times to present their arguments or switch arguments or parties and argue conversely. Law schools would benefit greatly by adopting and adapting from Hydra's improvisatory techniques what they currently lack in legal advocacy training: "the ability to listen deeply, critically, attentively, creatively, curiously, and intensively to the others around you" (Fischlin, Heble, and Lipsitz 196).

In addition, Hydra has the potential to

1. Create better relationships between students as future legal professionals. Shifting roles during the delivery of facts and legal submissions means that students do not listen to criticisms of their cases for prolonged periods, thus avoiding resentment of other students.

2. Create more imaginative arguments/judgments. Again, shifting roles means that students must often cope with not getting to deliver the final argument to the judge. This can lead to a stirring of ideas, since more room exists for creative exploration when there is less pressure to reach definitive conclusions.

3. Create a better understanding of different legal roles. Hydra allows for a greater appreciation of the roles lawyers play and the tactics they employ when on either side of a case. Focusing on one set of facts makes it easier to appreciate the position of other lawyers than wading through the shifting sands of different cases and legal issues.

4. Lead to more productive comprehension and use of vocal techniques, volume, and tone. Hydra teaches advocates how to use different tones for different witnesses-a sympathetic tone for children or vulnerable witnesses, an incredulous tone for rebutting witnesses who have presented contradictory evidence, or a calm tone for forwarding a favoured argument-and how to discern judicial preference.

5. Train students to better respond to witnesses who go "off-script" or act unpredictably. With its inclusion of rogue or "guerrilla" witnesses, Hydra promotes the rapid processing and recall of facts, legal submissions, and new evidence.

6. Train students to better respond to judicial interruptions. Participants must always be prepared for unexpected questions from "guerrilla" judges and be ready to switch tactics based on a judge's mood or body language.

\section{Conclusion}

Hydra has the potential to inspire creativity, criticality, and ethics in the lawyers of the future. In doing so, it may also redefine legal advocacy training as essentially improvisational in nature (Sawyer, "Creative Teaching" 12). What this means, following DeZutter's general philosophy on teaching, is that we should liken legal advocacy training to other professional training models "where conscious efforts are made to develop improvisational expertise, and where a body of knowledge has been built up for doing so" (27). In stark contrast to music and theatre, law does not have a "well-elaborated, shared notion of what constitutes excellent improvisation" (DeZutter 27). Without such a standard, we are letting down the legal advocates of the future, who will undoubtedly struggle to cope with unexpected or uncertain situations, both inside and outside the courtroomincluding those that emerge from the increasing percentage of litigants, especially in family law cases, who represent themselves (Grimwood 6). Hydra heralds a promising future, in its potential to alter the legal profession in creative and inspiring ways and to teach students and practitioners alike the significance of improvisational advocacy for ethical lawyering. 


\section{Acknowledgements}

The authors would especially like to acknowledge Dr. Kathryn McNeilly, and Dr. Matilde Meireles, who were instrumental in the creation of Hydra. We would also like to thank the members of the Translating Improvisation Research Group at Queen's University Belfast (QUB), especially those who partook in the improvisation workshop at QUB's Sonic Arts Research Centre (SARC) on June 25, 2014, where Zorn's Cobra was performed by members of QUBe. The development of Hydra relied heavily on the contributions and assistance of the participants in the initial pilot, which ran from December 2014 to February 2015 at QUB and included Ivanka Antova, Kathryn McNeilly, Matilde Meireles, Thomas Muinzer, Hannah Russell, and Timothy Waddell, in addition to the authors.

Hydra has been discussed, presented, and honed at various conferences and events across the UK, North America, and Australia, including the Keele University School of Law, England (2014); the Northern/Irish Feminist Judgments Project Drafting Workshop, QUB (2014); the Osgoode Hall Law School, Canada (2015); the Georgetown University Law Centre, Washington, D.C. (2015 and 2018); the Social Research Association, British Library, London (2015); the "Just Improvisation" Symposium, QUB (2015); the University of Victoria Faculty of Law, Canada (2017); the "Still Listening Conference in Memory of Pauline Oliveros," McGill University, Montreal, Canada (2017); and Melbourne Law School, Australia (2017). The feedback from audience members at these events has been invaluable.

We also thank the comments of the anonymous reviewers, who were instrumental in honing and strengthening our arguments.

Finally, we warmly thank the UK Arts and Humanities Research Council for its generous funding of the research project Into the Key of Law: Transposing Musical Improvisation. The Case of Child Protection in Northern Ireland, without which Hydra might very likely have never been invented and cultivated.

\section{Notes}

1 Sara Ramshaw is an Associate Professor at the University of Victoria Faculty of Law in British Columbia, Canada; Adnan Marquez-Borbon is an Independent Sonic Arts Researcher based in Ensenada, Baja California, Mexico; Seamus Mulholland is a Barrister-at-Law of the Bar of Northern Ireland, UK; and Paul Stapleton is a Senior Lecturer in Music at the Sonic Arts Research Centre, Queen's University Belfast.

All four authors were members of Into the Key of Law, a project funded by the UK Arts and Humanities Research Council (AHRC). Between July 2014 and December 2015, this research team organized interviews, focus groups, and other events with Northern Irish judges, lawyers, policy makers, social and charity sector workers, and local and international improvising musicians to explore the relationship between improvisatory music practices and child protection law. For more information, see translatingimprovisation.com/ahrc.

2 In the UK, solicitors provide expert legal advice and support, but only barristers may represent clients in court or before tribunals. In Canada, the United States, and Australia, the term "lawyer" is used more broadly to signify anyone licensed to provide legal advice.

${ }^{3}$ For more on this, see the discussion on page 6 about the "dark side of improvisation."

${ }^{4}$ We are aware that improvisation is not essentially inventive, nor is all improvisation new or innovative. In fact, as Landgraf has noted, the notion that improvisation must create something original is actually a "particularly modern understanding of improvisation" (6, emphasis added). For more on this, see Landgraf $(6,27)$ and Derrida $(49,54)$.

5 Time and again, it was noted by participants in the Into the Key of Law research project that limited resources, in terms of judicial time and government funding, place significant limits on the ability of judges, barristers, and others in the legal profession to think and act innovatively in response to problems in the legal system.

${ }^{6}$ In October 2015, Dame Keegan (styled The Hon Mrs Justice Keegan) and Dame Denise McBride (DBE, QC, styled The Hon Madam Justice McBride) were appointed as the first female judges of the High Court of Northern Ireland, and the following month, the Queen of England conferred both Justices with the honour of DBE (Dame of the British Empire): www.gov.uk/government/news/damehoods-conferred-siobhan-keegan-and-denise-mcbride. 
7 The "Just Improvisation: Enriching Child Protection Law Through Musical Techniques, Discourses and Pedagogies" Symposium was held at the Queen's University Belfast (QUB) Sonic Arts Research Centre (SARC) on 29-30 May 2015 and was sponsored by the Arts and Humanities Research Council (AHRC) of the United Kingdom.

${ }^{8}$ Audio-video footage of the panel can be found at translatingimprovisation.com/portfolio/symposium. Thanks to Seamus Mulholland for the transcription. Any mistakes are our own.

For more on the "myriad outworkings" of law, see Simon Rose's essay in this Special Issue.

${ }^{9}$ For more on the improvisation already taking place in judicial decision-making, see McNeilly and Stapleton's piece in this Special Issue.

${ }^{10}$ Although "ethical" advocacy is extremely difficult to define, for the purposes of this paper, we view it as an openness or attunement to otherness, as a willingness to be affected by the other (Mesle 71).

11 Moreover, as noted by Flood, "[o]ne essential component of legal education is the teaching of professional responsibility and legal ethics" (8). It is important to note that, in the United Kingdom at least, legal ethics is not taught in law school, but instead during postgraduate vocational courses such as the Bar Practice Course (BPC) for potential barristers and the Legal Practice Course (LPC) for potential solicitors (8-9).

\footnotetext{
12 See Robin Moore's article, "The Decline of Improvisation in Western Art Music."

${ }^{13}$ See page 6 for a discussion of the "dark side of improvisation" in law and how legal improvisation might differ from artistic/musical/pedagogical improvisation.
}

${ }^{14}$ Guerrilla tactics invoked by performers of Cobra include ignoring the instructions from the prompter and running separate "tactics" that allow them to control the actions of other players in the ensemble, including the prompter.

15 Zorn did publish a Cobra "score," the authorized version of which includes "(c) NYC, October 9, 1984," although it was not actually made publicly available by Zorn until the early 1990s. Notably, this version of the score lacks the instructions necessary to interpret the symbols on the score. Some instructions exist through interviews with Zorn, but most interpretations are indeed from some level of oral transmission, and different strands of this oral tradition have since been documented in diverse ways. For more information, see Brackett. A copy of the "score" can also be found here: hermes.neocities.org/zorn-cobra-score.pdf.

${ }^{16}$ There is an interesting paradox here in that Zorn's exertion of control has enabled a subversion of that control. Thanks to the anonymous reviewer who remarked on this paradox.

\section{See www.paulstapleton.net/portfolio/qube for more information on QUBe.}

18 John Brackett's article was written in celebration of the twenty-fifth anniversary of Cobra in 2009. It details how the musical game is "played" and the type of community imagined by Zorn in relation to it and his other game pieces, and situates Cobra in relation to various musical works composed by Zorn in the late 1970s and 80 s.

${ }^{19}$ For more information, see www.translatingimprovisation.com. This event was sponsored by the Institute for Collaborative Research in the Humanities (ICRH) at QUB.

20 Interestingly, at a recent presentation of Hydra at the "Still Listening Conference in Memory of Pauline Oliveros" (Montreal, 2 June 2017), Eric Lewis (Professor of Philosophy at McGill University and a trumpet player with much experience playing Cobra) was intrigued by our characterization of Hydra as a tool for teaching law students how to become better improvisers. In his experience, one has to be a very skilled musical improviser before participating in Cobra.

In a follow-up e-mail on June 14, 2017, Lewis explains that "Cobra demands of one to play certain ways at certain times on command. This is anathema to improvisational pedagogy." It also "does not allow for the completion/modification of musical ideas," something else Lewis argues is necessary to teach skilled improvisation. The dialogical nature of improvisation is, in fact, constrained in Cobra: musicians are, in effect, told "what to say, and when to speak." Thus, it is difficult for Lewis to not see Cobra as a means of "reinscribing the hierarchies inherent in the orchestral musical tradition (conductor, etc.) into a more improvisatory context": while "already expert improvisers can handle these constraints without it negatively impacting their ability to improvise," he "would not use it, or related methods, to teach folks to improvise." 
While we respect Lewis' hesitation to use Cobra to teach musical improvisation to novices, the experience of musicians in QUBe perhaps tells otherwise. Moreover, it is our belief that Hydra, as the only explicit opportunity to teach improvisational skills to novice legal advocates and law students, is a welcome addition to any law school, either as an extra-curricular activity or a component of the curriculum itself.

21 This pilot ran from December 2014 to February 2015 at QUB. Participants included Ivanka Antova, Adnan Marquez-Borbon, Kathryn McNeilly, Matilde Meireles, Thomas Muinzer, Seamus Mulholland, Sara Ramshaw, Hannah Russell, Paul Stapleton, and Timothy Waddell.

22 The "Local Authority / Trust" in the UK is equivalent to "Social Services" in North America.

${ }^{23}$ Ramshaw was, until recently, a professor at this school.

${ }^{24}$ A similar statement can be found on the University of Exeter Law School's website under "Why moot?": socialsciences.exeter.ac.uk/law/study/mooting/.

25 Stephen J. Greenblatt goes further to argue that improvisation is fundamentally corrupt and exploitative, concomitant to modes of (primarily) Western power that "both capitalize on the unforeseen and transform given materials into one's own scenario." Less concerned with its allegedly spontaneous nature, Greenblatt views improvisation as "the opportunistic grasp of that which seems fixed and established." According to this view, there is in improvisation no true "reciprocity," only a unilateral exploitation by those willing and able "to play a role, to transform [themselves], if only briefly and with mental reservations, into another" (60-63).

${ }^{26}$ The employment status of barristers in the United Kingdom is notably different from that of trial lawyers (or any lawyer for that matter) in North America. Most North American lawyers are employed in businesses called "partnerships," whereas barristers in the UK are generally prohibited from forming partnerships (although there are some exceptions). The idea behind the self-employment of UK barristers is to preserve their independence and allow them to do what they believe to be in the best interests of their clients, uninhibited by what anyone else in a business relationship with them might or would desire.

\section{Works Cited}

Attridge, Derek. The Singularity of Literature. Routledge, 2004.

Bailey, Derek. Improvisation: Its Nature and Practice in Music. 2nd ed. Da Capo, 1992.

Beghetto, Ronald and James Kaufman. "Teaching for Creativity with Disciplined Improvisation." Structure and Improvisation in Creative Teaching, edited by R. Keith Sawyer, Cambridge UP, 2011, pp. 94-109.

Borgo, David. "Free Jazz in the Classroom: An Ecological Approach to Music Education." Jazz Perspectives, vol. 1, no. 1, 2007, pp. 61-88.

Brackett, John. "Some Notes on John Zorn's Cobra." American Music, vol. 28, no. 1, 2010, pp. 44-75.

Cooper, James. "Towards a New Architecture: Creative Problem Solving and the Evolution of Law." California Western Law Review, vol. 34, no. 2, 1997, pp. 297-323.

Daicoff, Susan. "Law as a Healing Profession: The Comprehensive Law Movement." Pepperdine Dispute Resolution Law Journal Fall, vol. 6, no. 1, 2005, pp. 6-12.

Derrida, Jacques. "Psyche: Inventions of the Other." Translated by Catherine Porter. Reading de Man Reading, edited by Lindsay Waters and Wlad Godzich, U of Minnesota P, 1989, pp. 25-65.

DeZutter, Stacey. "Professional Improvisation and Teacher Education: Opening the Conversation." Structure and Improvisation in Creative Teaching, edited by R. Keith Sawyer, Cambridge UP, 2011, pp. 27-50.

Erickson, Frederick. "Taking Advantage of Structure to Improvise in Instruction: Examples from Elementary School Classrooms." Structure and Improvisation in Creative Teaching, edited by R. Keith Sawyer, Cambridge UP, 2011, pp. 113-132.

Fischlin, Daniel. "Wild notes' . . Improvisioning." Critical Studies in Improvisation / Études critiques en improvisation, vol. 6, no. 2, 2010, www.criticalimprov.com/article/view/1358/1937. 
Fischlin, Daniel, and Ajay Heble. "The Other Side of Nowhere: Jazz, Improvisation, and Communities in Dialogue." The Other Side of Nowhere: Jazz, Improvisation, and Communities in Dialogue, edited by Daniel Fischlin and Ajay Heble, Wesleyan UP, 2004, pp. 1-42.

Fischlin, Daniel, Ajay Heble, and George Lipsitz. The Fierce Urgency of Now: Improvisation, Rights, and the Ethics of Cocreation. Duke UP, 2013.

Flood, John. "Transnational Lawyering: Clients, Ethics and Regulation." Lawyers in Practice: Ethical Decision Making in Context, edited by Lynn Mather and Leslie Levin, U of Chicago P, 2012, pp. 176-196, www.johnflood.com/pdfs/Transnational_Lawyering_2010.pdf.

Greenblatt, Stephen. "Improvisation and Power." Literature and Society, edited by Edward Said, Johns Hopkins UP, 1980, pp. 57-99.

Grimwood, Gabrielle. Litigants in Person: The Rise of the Self-Represented Litigant in Civil and Family Cases. London: House of Commons Library, 2016. Briefing Paper Number 07113.

Kerper, Janeen. "Creative Problem Solving vs. the Case Method: A Marvelous Adventure in which Winnie-thePooh Meets Mrs. Palsgraf." California Western Law Review, vol. 34, no. 2, 1997, pp. 351-374.

Keyes, Mary, and Richard Johnstone. "Changing Legal Education: Rhetoric, Reality, and Prospects for the Future." Sydney Law Review, vol. 26, 2004, pp. 537-564.

Krieger, Stefan. "Domain Knowledge and the Teaching of Creative Legal Problem Solving." Clinical Law Review, vol. 11, 2004, pp. 149-207.

Landgraf, Edgar. Improvisation as Art: Conceptual Challenges, Historical Perspectives. Continuum, 2011.

Lange, Barbara Rose. "Teaching the Ethics of Free Improvisation." Critical Studies in Improvisation / Études critiques en improvisation, vol. 7, no. 2, 2011, www.criticalimprov.com/article/view/964/2309.

Lewis, George E. "Improvisation and Pedagogy: Background and Focus of Inquiry." Critical Studies in Improvisation / Études critiques en improvisation, vol. 3, no. 2, 2007, www.criticalimprov.com/article/view/412/659.

Little, Laura E. "Conflict of Laws Structure and Vision: Updating a Venerable Discipline." Georgia State University Law Review, vol. 31, no. 2, 2015, pp. 231-287.

Lynch, Andrew. "Why Do We Moot? Exploring the Role of Mooting in Legal Education." Legal Education Review, vol. 7 , no. 1, 1996, pp. 67-96.

Macfarlane, Julie. "Look Before You Leap: Knowledge and Learning in Legal Skills Education." Journal of Law and Society, vol. 19, no. 3, 1992, pp. 293-319.

McMullen, Tracey. "Improvisation within a Scene of Constraint: An Interview with Judith Butler." Negotiated Moments: Improvisation, Sound, and Subjectivity, edited by Gillian Siddall and Ellen Waterman, Duke UP, 2016, pp. 21-33.

Menkel-Meadow, Carrie. "The Lawyer as Problem Solver and Third-Party Neutral: Creativity and Nonpartisanship in Lawyering." Temple Law Review, vol. 72, 1999, pp. 785-810.

Mesle, Rober C. Process-Relational Philosophy: An Introduction to Alfred North Whitehead. Templeton, 2008.

Moore, Robin. "The Decline of Improvisation in Western Art Music: An Interpretation of Change." International Review of the Aesthetics and Sociology of Music, vol. 23, no. 1, 1992, pp. 61-84.

Mooting Handbook. University of Exeter Law School, 2013.

Oliveros, Pauline. Deep Listening: A Composer's Sound Practice. iUniverse, 2005.

Prouty, Ken. "The 'Finite' Art of Improvisation: Pedagogy and Power in Jazz Education." Critical Studies in Improvisation / Études critiques en improvisation, vol. 4, no. 1, 2008, www.criticalimprov.com/article/view/346/966. 
Ramshaw, Sara. "The Creative Life of Law: Improvisation, Between Tradition and Suspicion." Critical Studies in Improvisation / Études critiques en improvisation, vol. 6, no. 1, 2010, www.criticalimprov.com/article/view/1084/1700.

---. "Deconstructin(g) Jazz Improvisation: Derrida and the Law of the Singular Event." Critical Studies in Improvisation / Études critiques en improvisation, vol. 2, no. 1, 2006, www.criticalimprov.com/article/view/81/188.

---. "Improvising (II)legality: Justice and the Irish Diaspora, NYC, 1930-1932." Irish Journal of Legal Studies, vol. 3, no. 1, 2013, pp. 90-121.

---. “Jamming the Law: Improvised Theatre and the 'Spontaneity' of Judgment." Law Text Culture, vol. 14, no. 1, 2010, pp. 133-159.

---. Justice as Improvisation: The Law of the Extempore. Routledge, 2013.

Rogers, Krista Riddick. "Promoting a Paradigm of Collaboration in an Adversarial Legal System: An Integrated Problem Solving Perspective for Shifting Prevailing Attitudes from Competition to Cooperation within the Legal Profession." Barry Law Review, vol. 6, 2006, pp. 137-161.

Ross, David. "Activating Bodies of Knowledge: Improvisation, Cognition, and Sports Education." Critical Studies in Improvisation / Études critiques en improvisation, vol. 7, no. 2, 2011, www.criticalimprov.com/article/view/1314/2234.

Sawyer, R. Keith. "Creative teaching: Collaborative discussion as disciplined improvisation." Educational Researcher, vol. 33, 2004, pp. 12-20.

---. "Improvisation and Teaching." Critical Studies in Improvisation / Études critiques en improvisation, vol. 3, no. 2, 2007, www.criticalimprov.com/article/view/380/626a.

---. "What Makes Good Teachers Great? The Artful Balance of Structure and Improvisation." Structure and Improvisation in Creative Teaching, edited by R. Keith Sawyer, Cambridge UP, 2011, pp. 1-24.

Shaw, Patricia, and Ralph Stacey, editors. Experiencing Risk, Spontaneity and Improvisation in Organizational Change: Working Live. Routledge, 2006.

Thomson, Scott. "The Pedagogical Imperative of Musical Improvisation." Critical Studies in Improvisation / Études critiques en improvisation, vol. 3, no. 2, 2007, www.criticalimprov.com/article/view/353/643.

Todorov, Tzvetan. The Conquest of America: The Question of the Other. U of Oklahoma P, 1999.

van der Schyff, Dylan. “The Free Improvisation Game: Performing John Zorn's Cobra.” Journal of Research in Music Performance, 2013, https://ejournals.lib.vt.edu/JRMP/article/view/726/1040.

Winick, Bruce J., and David B. Wexler, editors. Judging in a Therapeutic Key: Therapeutic Jurisprudence and the Courts. Carolina Academic Press, 2003.

Wolski, Bobette. "Beyond Mooting: Designing An Advocacy, Ethics And Values Matrix For The Law School Curriculum." Legal Education Review, vol. 19, no. 1, 2009, pp. 41-82.

\section{APPENDIX A: Rules of the Beginner's Version of Hydra}

1. Prior to the performance of Hydra, the law and fact scenario to be used must be finalized and distributed to the participants several days in advance, such that they can learn the material and perhaps do further research on the issues. It is best to make the legal rules as simple as possible, allowing the facts to drive the performance.

2. Immediately prior to the performance, it is useful to partake in some improvisational movement and vocal exercises to help lessen the stress and inhibitions of the participants and get their creative juices flowing.

3. Participants divide themselves into the following roles: 


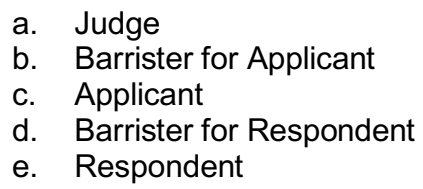

In child protection cases, additional participants include

f. Barrister for Local Authority (LA) or Trust

g. LA / Trust Social Worker

4. The performance begins with the judge introducing the case, including a brief overview of the law and facts to provide some context.

5. When the A (Advocate) card is held up by the judge, driven either by the judge or by a "talking" gesture from a participant, argument begins at the direction of and on the "downswing" of the judge's arm/gavel.

6. When a participant wishes to argue, she/he signals to the judge, using the Advocate gesture, and the judge either allows the participant to rise and begin argument, at which time the person talking must stop arguing and sit down, or holds a stop hand signal until she/he decides the current argument should stop. Argument begins on the downswing.

7. A participant who wants to begin argument as counsel must first take the wig from the head of the person beside her/him before signaling to the judge that she/he wishes to speak.

8. Counsel who wishes to stop arguing can place her/his wig on the person beside her/him.

9. Any participant can interrupt the proceedings by walking to the witness stand and picking up a witness name, placed face down on the witness box. The judge asks the witness to state her or his name for the record so that the other participants know who the witness is. The barrister currently arguing begins either cross-examining or examining-in-chief. The witness can return to her or his original position at any time. Other rules do not apply to the witness.

10. The judge can, at any time, ask the standing barrister questions regarding the case or her/his argument. The questions end at the will of the judge.

11. The judge, at any time, can switch positions with one of the other participants. That participant must then take on the judicial role until she/he takes the position of another participant. [Note: this action has not yet been honed, as it did not exist during the initial pilot.]

12. The performance ends when the judge holds up the End card, either by choice, or because a participant brings a fist down on her/his palm. Participants can veto an End card by making the cut-throat signal (see below), to a maximum of 3 times per performance.

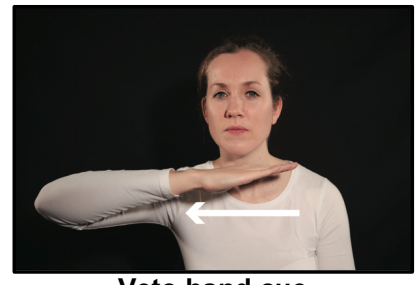

Veto hand cue

A short video of a pilot session of Hydra held at Queen's University Belfast can be accessed via the following link: translatingimprovisation.com/hydra. Please note that the video was recorded prior to certain changes being made to Hydra, and thus some cards and cues are different from the current version. If you would like a copy of the booklet outlining the latest version, please contact the authors.

\section{APPENDIX B: Hydra - Example Case*}

\section{Opening Statement By Her Honour Judge Ramshaw High Court of Northern Ireland, Family Division}

Welcome. You are about to witness legal argument in the Welfare Stage of a care order proceeding in the High Court of Northern Ireland, Family Division. 
This is an application pertaining to an 8-year old little girl, Jane Dahl-Pierson, whose baby sister, Joanne, died on 3 January 2014 with the following injuries: multiple rib fractures caused by deliberate physical abuse; nonaccidental bruises to her face, shoulder and arm; and severe untreated nappy rash. The cause of death was asphyxia by obstruction of her airways (although it was undetermined whether this was deliberate or by accident). Both parents, Derek Pierson and Maggie Dahl, who are currently separated, were charged with the murder of Joanne, but were acquitted of the charges in Belfast on 7 July 2014. Derek was additionally charged with assault occasioning actual bodily harm on Maggie. He is currently out on bail awaiting resolution.

At the threshold stage of the proceedings, I was unable to find definite evidence (proven on a balance of probabilities) that linked one or the other parent to Joanne's injuries, but found that the harm had to be inflicted by one or both of them. I did find, though, that it was beyond doubt that the parents had been lying about what happened to hide the truth. As such, I found it likely that Jane would suffer significant harm in the future due to a lack of reasonable parental care, and thus the threshold test in Article 50 of the Children (NI) Order had been crossed.

I am now tasked with determining what order, if any, should be made at the Welfare Stage of the proceedings. To do so, I must take into consideration the paramount consideration of Jane's welfare by reference to the Welfare Checklist in Article 3 (3) of the Children Order (NI) 1995, such as her wishes and feelings (considered in the light of her age and understanding), the risk of harm to her, and the capabilities of the parents to meet her needs. I must also consider the human rights of the parties, such as the Article 8 right to family and private life and the Article 3 right to be free from torture or inhuman and degrading treatment or punishment.

The following orders are possible:

(1) Care Order: typically, the child is removed from the family and placed with foster parents or relatives. The local authority is given parental responsibility of the child.

(2) Supervision Order: this order directs the local authority to "advise, assist and befriend" a family, but does not give the authority parental responsibility over the child. It is viewed to be most useful in situations where the actual or potential harm is not as severe and the family is extremely cooperative.

(3) Residence Order: as an alternative to placing the child in care, the judge can direct that the child reside with either a parent or a relative. Persons with a residence order (Article 8) in their favour also obtain parental responsibility of the child, which they share with others who have parental responsibility.

(4) No Order: a judge shall not make an order unless doing so would be better for the child than making no order at all.

(5) Contact Order: this order directs with whom the child should have contact after one of the above orders is made.

The parties to this proceeding include the mother, the father, and the local trust.

* This example case was drafted by Seamus Mulholland, BL. 